\title{
PENGARUH TEKNOLOGI INFORMASI DAN ACCOUNTING REPORTING TERHADAP PENCEGAHAN FRAUD
}

\author{
Rini Widianingsih', Siti Maghfiroh ${ }^{2}$, Agus Sunarmo ${ }^{3}$ \\ Fakultas Ekonomi dan Bisnis, Universitas Jenderal Soedirman ${ }^{1,2,3}$ \\ ri3n.wibowo@gmail.com
}

\begin{abstract}
The purpose of this research is to examine the impact of information technology, accounting reporting toward fraud detection in companies that listed on Indonesia Stock Exchange. The population of the study is the LQ 45 companies registered in the Indonesia Stock Exchange in the period of 2012-2016. Sampling technique employed in this study is the purposive sampling with the total sample of 90 companies. The data analysis uses SPSS software. The result of the study shows that the, information technology, accounting reporting have significant influence towards fraud detection.
\end{abstract}

Keywords: Information technology, accounting reporting, fraud detection.

ABSTRAK

Tujuan dari penelitian ini adalah untuk menguji dampak teknologi informasi, pelaporan akuntansi terhadap deteksi kecurangan pada perusahaan yang terdaftar di Bursa Efek Indonesia. Populasi penelitian adalah perusahaan LQ 45 yang terdaftar di Bursa Efek Indonesia pada periode 2012-2016. Teknik pengambilan sampel yang digunakan dalam penelitian ini adalah purposive sampling dengan jumlah sampel 90 perusahaan. Analisis data menggunakan perangkat lunak SPSS. Hasil penelitian menunjukkan bahwa, teknologi informasi, pelaporan akuntansi memiliki pengaruh signifikan terhadap deteksi kecurangan.

Kata kunci: teknologi informasi, pelaporan akuntansi, deteksi fraud

\section{PENDAHULUAN}

Perkembangan teknologi informasi mempunyai pengaruh yang luas terhadap aspek bisnis. Teknologi informasi dicanangkan untuk membantu perusahaan dalam melaksanakan kegiatan operasionalnya sehari-hari. Impelementasi teknologi informasi dalam perusahaan membuat kinerja semakin meningkat . Dengan teknologi informasi yang sistematis dan terintegrasi akan semakin mempersempit celah terjadinya fraud dalam perusahaan. Selain teknologi informasi, faktor lain yang tak kalah penting dalam pencegahan fraud adalah accounting reporting. Accounting reporting merupakan komponen penting untuk menciptakan akuntabilitas organisasi. Adanya tuntutan yang semakin besar terhadap pelaksanaan akuntabilitas publik menimbulkan implikasi bagi manajemen untuk memberikan informasi kepada publik, salah satunya adalah informasi akuntansi yang berupa laporan keuangan. Tantangan yang dihadapi accounting reporting adalah rnampukah akuntansi menyediakan informasi yang 
dapat digunakan untuk memonitor akuntabilitas manajemen, akuntabilitas politik, dan akuntabilitas kebijakan. Salah satu bentuk pencegahah fraud adalah dengan menyajikan accounting reporting yang sesungguhnya dengan mempertimbangkan hal penerapan kebijakan, sistem dan prosedur yang membantu menyakinkan bahwa tindakan yang diperlukan sudah dilakukan dewan komisaris, serta manajernen dan personil lain perusahaan untuk dapat memberikan kenyakinan memadai.

Penelitian ini mencoba menelaah pengaruh kebijakan deviden, aplikasi teknologi informasi, accounting reporting terhadap pencegahan fraud serta implikasinya terhadap reaksi investor dalam menilai kinerja perusahaan.

\section{TINJAUAN PUSTAKA DAN PENGEMBANGAN HIPOTESIS \\ Teknologi Informasi terhadap Pencegahan Fraud}

Menurut O'Brien (2006) teknologi adalah suatu jaringan komputer yang terdiri atas berbagai komponen pemrosesan informasi yang menggunakan berbagai jenis hardware, software, manajemen data, dan teknologi jaringan informasi. Menurut Aji (2005) informasi adalah data yang terolah dan sifatnya menjadi data lain yang bermanfaat dan biasa disebut informasi. Pemanfaatan teknologi informasi menurut Thomson et al. (1991) dalam Tjhai (2003) merupakan manfaat yang diharapkan oleh pengguna sistem informasi dalam melaksanakan tugasnya atau perilaku dalam menggunakan teknologi pada saat melakukan pekerjaan. Jones dan Bates (Jones, 1990) dalam Public Sector Auditing raud dalam Thef Act 1968 adalah penggelapan yang meliputi berbagai kecurangan, antar lain penipuan yang disengaja (intentional deceit), pemalsuan rekening (falsification of account), praktek jahat (corrupt practices), penggelapan atau pencurian (embezzlement), korupsi (corruption) dan sebagainya

Teknologi informasi telah membawa perubahan yang sangat mendasar bagi organisasi baik swasta maupun organisasi publik. Oleh karena itu, teknologi informasi menjadi suatu hal yang sangat penting dalam menentukan daya saing dan kemampuan perusahaan untuk meningkatkan kinerja bisnis di masa mendatang. Sumber daya teknologi informasi menjadi sebuah pertimbangan baik itu bagi para manajer dan konsultan, dalam menentukan keberhasilan perusahaan di masa mendatang (Devaraj dan Kohli, 2003). Implementasi teknologi informasi dapat memenuhi kebutuhan informasi dunia bisnis dengan sangat cepat, tepat waktu, relevan, dan akurat (Wilkinson dan Cerullo, 1997). Adanya implementasi teknologi informasi yang membantu kegiatan perusaahaan dalam menghasilkan informasi yang akurat tentunya sangat membantu mencegah terjadinya kecurangan dalam organisasi perusahaan,. Berdasarkan hal tersebut maka dikemukana hipotesis sebagai berikut :

\section{H1: Teknologi Informasi berpengaruh terhadap pencegahan fraud.}




\section{Accounting Reporting terhadap Pencegahan Fraud}

Laporan keuangan merupakan bentuk pertanggungjawaban atas kepengurusan sumber daya ekonomi yang dimiliki oleh suatu entitas (Deddi Nordiawan, 2007). Seperti yang diungkap pula oleh Kieso, Weygant (2005) bahwa, report that measures the success of enterprise operations for a given period of time. Sedangkan menurut Peraturan Pemerintah Nomor 24 Tahun 2005, Laporan Keuangan merupakan laporan terstruktur mengenai posisi keuangan dan transaksi-transaksi yang dilakukan oleh suatu entitas pelaporan.

Tujuan penyajian laporan keuangan menurut Jones (2000) yaitu "To provide (1) financial information usefull for making economic and (2) information usefull for evaluating managerial and organizational performance". Sedangkan Wolk (2001) menyatakan bahwa: "An objective of financial statements for govermental and not-for-profit organizations is to provide information useful for evaluating the effectiveness of the management of resources in achieving the organization's goals. Dalam PSAK no 45 "Pelaporan Keuangan Organisasi Nirlaba" mengemukakan tujuan utama laporan keuangan adalah menyediakan informasi yang relevan untuk memenuhi kepentingan para penyumbang, anggota organisasi, kreditur dan pihak lain yang menyediakan sumber daya bagi kegiatan organisasi nirlaba.

Accounting reporting merupakan komponen penting untuk menciptakan akuntabilitas organisasi. Salah satu bentuk pencegahah fraud adalah dengan menyajikan accounting reporting yang sesungguhnya dengan mempertimbangkan hal penerapan kebijakan, sistem dan prosedur yang membantu menyakinkan bahwa tindakan yang diperlukan sudah dilakukan dewan komisaris, serta manajernen dan personil lain perusahaan untuk dapat memberikan kenyakinan memadai. Penelitian yang dilakukan oleh Santoso (2008) membuktikan bahwa penerapan accounting report di sector public terbukti mencegah terjadinya fraud. Berdasarkan paparan di atas maka dikemukakan hipotesis sebagai berikut :

\section{H2: Accounting reporting berpengaruh terhadap pencegahan fraud.}

\section{METODE PENELITIAN}

\section{Populasi dan Sampel}

Populasi yang akan menjadi objek penelitian adalah perusahaan-perusahaan LQ 45 yangterdaftar di Bursa Efek Jakarta periode 2012 - 2016 . Pemilihan sampel perusahaan LQ 45 pada penelitian ini dikarenakan perusahaan LQ 45 di Indonesia rentan terhadap perubahan yang terjadi di bidang lainnya seperti bidang sosial, politik, keamanan, baik yang terjadi di dalam negeri. Bursa Efek Jakarta merupakan pasar saham terbesar dan paling representatif di Indonesia. Berdasarkan populasi tersebut dapat ditentukan sampel yang menjadi objek penelitian ini. 


\section{Teknik Pengambilan Sampel}

Dalam penentuan sampel tersebut, teknik sampling yang dipergunakan adalah purposive sampling yaitu metode pengambilan sampling berdasarkan kriteria-kriteria tertentu (Singarimbun dan Effendi, 1995).

\section{Uji Kualitas Data}

Menurut Hair dkk (1995) kualitas data yang dihasilkan dari penggunaan instrumen penelitian dapat dievaluasi melalui uji reliabilitas dan validitas. Uji tersebut masing-masing untuk mengetahui konsistensi dan akurasi data yang dikumpulkan dari penggunaan instrumen. Ada 2 prosedur yang dilakukan untuk mengukur reliabilitas dan validitas data, yaitu: uji konsistensi internal terhadap jawaban responden atas instrumen penelitian dan uji validitas konstruk dengan cara mengkorelasikan antara skor masing-masing item dan skor totalnya. Keterangan dari kedua uji kualitas data adalah sebagai berikut:

1. Uji konsistensi internal (reliabilitas) ditentukan dengan koefisien cronbach alpha. Suatu konstruk atau instrumen dikatakan reliabel jika memberikan nilai cronbach alpha di atas 0,60 (Nunnally, 1967 dalam Imam, 2005).

2. Uji homogenitas data (validitas) dengan uji person correlation. Jika hasilnya signifikan maka data dikatakan valid.

\section{Uji Normalitas}

Uji normalitas bertujuan untuk menguji apakah dalam model regresi, variabel pengganggu atau residual memiliki distribusi normal. Seperti diketahui bahwa uji $\mathrm{t}$ dan $\mathrm{F}$ mengasumsikan bahwa nilai residual mengikuti distribusi normal. Kalau asumsi ini dilanggar maka uji statistik menjadi tidak valid untuk jumlah sampel yang kecil. Salah satu uji statistik yang dapat digunakan untuk menguji normalitas residual adalah uji statistik non-parametrik KolmogorovSmirnov (K-S).

\section{Uji Asumsi Klasik}

\section{Uji Multikolonearitas}

Uji multikolonearitas bertujuan untuk menguji apakah model regresi ditemukan adanya korelasi antar variabel bebas (independen). Model regresi yang baik seharusnya tidak terjadi korelasi diantara variabel independen. Jika variabel independen saling berkolerasi, maka variabel-variabel ini tidak ortogonal. Variabel ortogonal adalah variabel independen yang nilai korelasi antar sesama variabel independen sama dengan nol. Identifikasi keberadaan multikolonearitas ini dapat didasarkan pada nilai tolerance dan Varience Inflation Factor (VIF). Apabila nilai VIF $>10$ dan nilai tolerance $<0,10$ maka tidak terjadi multikolinearitas antar variabel independennya. (Ghozali, 2006:92). 


\section{Uji Autokorelasi}

Uji autokorelasi bertujuan untuk mendeteksi tingkat keeratan suatu hubungan, asumsi ini dedefinisikan sebagai terjadinya korelasi diantara dua pengamatan, dimana munculnya suatu data dipengaruhi oleh data sebelumnya. Jika terjadi korelasi maka dinamakan ada problem autokorelasi. Dalam penelitian ini menggunakan uji Durbin-Watson (DW test) untuk mengetahui ada tidaknya problem autokorelasi dalam model regresi. Tabel 1 menampilkan kriteria dari uji Durbin-Watson (DW test).

\section{Tabel 1. Tabel uji Durbin-Watson}

\begin{tabular}{lll}
\hline \multicolumn{1}{c}{ Hipotesis Nol } & \multicolumn{1}{c}{ Keputusan } & \multicolumn{1}{c}{ Jika } \\
\hline Tidak ada autokorelasi positif & Tolak & $0<\mathrm{d}<\mathrm{d}_{1}$ \\
Tidak ada autokorelasi positif & No decision & $\mathrm{D}_{\mathrm{l}} \leq \mathrm{d} \leq \mathrm{d}_{\mathrm{U}}$ \\
Tidak ada autokorelasi negatif & Tolak & $4-\mathrm{d}_{1} \leq \mathrm{d} \leq 4$ \\
Tidak ada autokorelasi negatif & No decision & $4-\mathrm{d}_{\mathrm{u}} \leq \mathrm{d} \leq 4-$ \\
& & $\mathrm{d}_{\mathrm{l}}$ \\
Tidak ada autokorelasi positif atau negatif & Tidak dapat ditolak & $\mathrm{d}_{\mathrm{u}}<\mathrm{d}<4-\mathrm{d}_{\mathrm{u}}$ \\
\hline
\end{tabular}
Sumber: Ghozali, 2006:96

\section{Uji Hipotesis}

Analisis statistik yang digunakan adalah berganda sebagai model yang memprediksi hubungan kausal antara variabel dependen dengan beberapa variabel independen.

Persamaan statistika yang digunakan adalah sebagai berikut:

$$
\mathrm{Y}=\mathrm{a}+\mathrm{b} 1 \mathrm{x} 1+\mathrm{b} 2 \mathrm{x} 2+\mathrm{e}
$$

Dimana:

$$
\begin{array}{ll}
\mathrm{Y} & =\text { Pencegahan fraud } \\
\mathrm{a} & =\text { intercept } \\
\mathrm{x} 1 & =\text { Teknologi informasi } \\
\mathrm{x} 2 & =\text { Accounting reporting } \\
\mathrm{b} 1 & =\text { koefisien regresi teknologi informasi } \\
\mathrm{b} 2 & =\text { koefisien regresi Accounting reporting } \\
\mathrm{e} & =\text { error }
\end{array}
$$

\section{Uji Simultan (F)}

Uji Serentak atau uji simultan digunakan untuk menejelaskan pengaruh antara variabel dependen dengan semua variabel independen secara bersamasama.

\section{Uji Parsial (Uji t)}

Uji parsial (Uji t) digunakan untuk mengetahui secara parsial pengaruh masing-masing variabel independen $(\mathrm{Xi})$ terhadap variabel dependen $(\mathrm{Y})$. 


\section{HASIL PENGUJIAN HIPOTESIS DAN PEMBAHASAN Deskripsi Variabel}

Gambaran mengenai variabel-variabel penelitian yaitu teknologi informasi, accounting report dan pencegahan fraud disajikan dalam tabel statistik deskriptif yang menunjukkan angka kisaran teoritis dan sesungguhnya, rata-rata standar deviasi dapat dilihat dalam tabel 4.1. Apabila nilai rata-rata jawaban tiap konstruk pada kisaran sesungguhnya di bawah rata-rata kisaran teoritis maka dapat diartikan bahwa pengaruh variabel yang diteliti terhadap responden cenderung rendah. Begitu pula sebaliknya jika nilai rata-rata kisaran sesungguhnya di atas rata-rata kisaran teoritis, maka pengaruh variabel yang diteliti terhadap responden cenderung tinggi.

Tabel 2. Statistik Deskriptif Variabel Penelitian

\begin{tabular}{lcccccc}
\hline & $\mathrm{N}$ & Minimum & Maximum & \multicolumn{2}{c}{ Mean } & Std. Deviation \\
\hline & Statistic & Statistic & Statistic & Statistic & Std. Error & Statistic \\
\hline TI & 90 & 12,331 & 22.841 & 17.234 & .897 & 12.349 \\
AC & 90 & 11.445 & 23.063 & 18.890 & .145 & 13.543 \\
FR & 90 & 13.442 & 23.982 & 16.812 & .467 & 13.990 \\
Valid N & 90 & & & & & \\
(listwise) & & & & & & \\
\hline
\end{tabular}

Sumber: data diolah, 2018

Berdasarkan tabel di atas maka dapat diketahui bahwa variabel teknologi informasi memiliki nilai minimum 12,331, nilai maksimum 22,841, rata-rata 17,234 dan standar deviasi sebesar 12,349. Nilai standar deviasi yang lebih kecil dari nilai rata-rata menandakan perbedaan penggunaan teknologi informasi antar perusahaan adalah kecil. Nilai mean yang positif menunjukkan bahwa rata-rata perusahaan yang diteliti menggunakan teknologi informasi dalam kegiatan operasionalnya.

Variabel accounting reporting memiliki nilai minimum 11,455 nilai maksimum 23,063 rata-rata 18,890, dan standar deviasi sebesar 13,543. Nilai standar deviasi yang lebih kecil dari nilai rata-rata menandakan perbedaan accounting reporting antar perusahaan adalah kecil. Nilai mean yang positif menunjukkan bahwa rata-rata perusahaan yang diteliti melakukan aktivitas accouting report. Variabel fraud memiliki nilai minimum 13,442, nilai maksimum 23,982 rata-rata 16,812 dan standar deviasi sebesar 13,990. Nilai standar deviasi yang lebih kecil dari nilai rata-rata menandakan perbedaan lamanya pencegahan fraud antar perusahaan adalah kecil.

\section{Uji Normalitas}

Berdasarkan hasil output pada Tabel 3, variabel dinyatakan menyebar dengan normal jika hasil uji kolmogorov smirnov standarized residual 
menunjukkan jika nilai assympatic significant (2-tailed) > alpha $(0,05)$. Pada tabel, dapat diketahui bahwa nilai Kolmogorov Smirnov test sebesar 0,552 sedangkan nilai asymp. sig. (2-tailed) untuk unstandardized variable sebesar 0,578 lebih besar dari nilai a yaitu 0,05 , sehingga dapat disimpulkan bahwa data yang digunakan berdistribusi normal

Tabel 3. Hasil Uji Normalitas One-Sample Kolmogorov-Smirnov Test

\begin{tabular}{llr}
\hline & & $\begin{array}{r}\text { Unstandardized } \\
\text { Residual }\end{array}$ \\
\hline $\mathrm{N}$ & & 90 \\
Normal Parameters ${ }^{\mathrm{a}, \mathrm{b}}$ & Mean & .0000000 \\
& Std. Deviation & 4.14523562 \\
Most Extreme Differences & Absolute & .234 \\
& Positive & .023 \\
& Negative & -.234 \\
Kolmogorov-Smirnov Z & & .552 \\
Asymp. Sig. (2-tailed) & & .578 \\
\hline a. Test distribution is Normal. & \\
b. Calculated from data. &
\end{tabular}

\section{Uji Kualitas Data}

Uji kualitas data meliputi realibilitas dan uji validitas. Uji reliabitas dilakukan dengan uji cronbach alpha menggunakan SPSS. Suatu konstruk dikatakan reliabel jika memberikan nilai cronbach alpha >0,60 (Nunnaly, 1967 dalam Imam, 2005). Hasil secara lengkap uji reliabilitas dan validitas dapat dilihat pada tabel 4 dan Tabel 5.

Tabel 4. Hasil Uji Reabilitas

\begin{tabular}{clcc}
\hline No & Variabel & Nilai Cronbach Alpha & Keterangan \\
\hline 1 & Teknologi Informasi & 0.894 & Reliabel \\
2 & Accounting Reporting & 0.916 & Reliabel \\
3 & Pencegahan fraud & 0.893 & Reliabel \\
\hline
\end{tabular}

Sumber: Data diolah, 2018

Tabel 5. Hasil Uji Validitas

\begin{tabular}{lllcl}
\hline No & \multicolumn{1}{c}{ Variabel } & Kisaran Korelasi & Signifikansi & Keterangan \\
\hline 1 & Teknologi Informasi & $0.516^{* *-0.826^{* *}}$ & 0.01 & Valid \\
2 & Accounting Reporting & $0.726^{* *}-0.931^{* *}$ & 0.01 & Valid \\
3 & Pencegahan fraud & $0.688^{* *-0.855^{* *}}$ & 0.01 & Valid \\
\hline
\end{tabular}

Sumber: Data diolah, 2018 


\section{Uji Asumsi Klasik \\ Uji Multikolineritas}

Tabel 6. Hasil Uji Multikolinearitas

\begin{tabular}{lcccccccc}
\hline & \multicolumn{2}{c}{$\begin{array}{c}\text { Unstandardized } \\
\text { Coefficients }\end{array}$} & \multicolumn{2}{c}{$\begin{array}{c}\text { Standardized } \\
\text { Coefficients }\end{array}$} & & \multicolumn{3}{c}{$\begin{array}{c}\text { Collinearity } \\
\text { Statistics }\end{array}$} \\
\cline { 2 - 4 } \multicolumn{1}{c}{ Model } & B & Std. Error & Beta & t & Sig. & Tolerance & VIF \\
\hline $1($ Constant $)$ & 91.558 & 13.515 & & 6.775 & .000 & & \\
total_TI & .174 & .234 & .175 & .746 & .463 & .559 & 1.788 \\
Total_Acc & .234 & .251 & .167 & .934 & .359 & .963 & 1.038 \\
\hline
\end{tabular}

a. Dependent Variable: total_fraud

Sumber: Data diolah, 2018

Berdasarkan hasil pengujian pada tabel 4.5. dapat dilihat bahwa nilai VIF pada masing-masing variabel berjumlsh kurang dari 10 dan nilai tolerance kurang dari 1, sehingga dinyatakan semua variabel bebas dari gejala multikolinieritas.

\section{Uji Autokorelasi}

Tabel 7. Hasil Uji Autokorelasi

\begin{tabular}{lccccc}
\hline Model & R & R Square & $\begin{array}{c}\text { Adjusted R } \\
\text { Square }\end{array}$ & $\begin{array}{c}\text { Std. Error of } \\
\text { the Estimate }\end{array}$ & $\begin{array}{c}\text { Durbin- } \\
\text { Watson }\end{array}$ \\
\hline 1 & $.448^{\mathrm{a}}$ & .201 & .109 & 6.52770 & 1.116
\end{tabular}

a. Predictors: (Constant), total_TI, Total_ACC

b. Dependent Variable: total_fraud

Sumber: Data diolah, 2018

Berdasarkan hasil uji Durbin-Watson dengan bantuan software SPSS for Windows yang telah dilakukan, diperoleh nilai Durbin-Watson sebesar 1,116. Nilai tersebut dibandingkan dengan nilai Durbin Watson tabel untuk $\mathrm{n}=90$ dan $\mathrm{k}$ $=3$ dengan $(\alpha) 0,05$ atau $5 \%$, maka nilai $\mathrm{d}_{\mathrm{U}}=1,72$ dan $\mathrm{d}_{\mathrm{L}}=1,41$. Jadi nilai uji Durbin Watson berada di antara $\mathrm{d}_{\mathrm{U}}$ dan $4-\mathrm{d}_{\mathrm{U}}$. Hal ini merupakan bukti tidak adanya autokorelasi positif maupun negatif.

\section{Uji Hipotesis}

Untuk mengetahui pengaruh variabel teknologi informasi, accounting repoting terhadap pencegahan fraud dilakukan dengan metode analisis regresi berganda. Berikut adalah hasil analisis regresi linier berganda dengan Program SPSS. Tabel 8 menunjukkan hasil estimasi regresi berganda yang kemudian dapat dibuat persamaan sebagai berikut:

$$
Y=91,558+0,174 X_{1}+0,234 X_{2}+\varepsilon
$$


1. Nilai konstanta sebesar 91,558 yang berarti bila variabel teknologi informasi, accounting reporting sama dengan nol, maka pencegahan fraud 91,558.

2. Koefisien $\mathrm{X}_{1}$ sebesar 0,174 berarti variabel teknologi informasi mempunyai hubungan yang positif dengan variabel pencegahan fraud, hal ini menunjukkan bahwa naiknya variabel teknologi informasi akan menaikkan variabel pencegahan fraud pencegahan fraud. Jika terjadi kenaikan variabel teknologi informasi sebesar satu persen maka akan menaikkan variabel pencegahan fraud sebesar 17,4 persen, dengan asumsi bahwa variabel lain tetap pada tingkat kepercayaan 95 persen.

3. Koefisien $\mathrm{X}_{2}$ sebesar 0,234 berarti berarti variabel accounting reporting mempunyai hubungan yang positif dengan variabel pencegahan fraud, hal ini menunjukkan bahwa naiknya variabel accounting reporting akan menaikkan variabel pencegahan fraud. Jika terjadi kenaikan accounting reporting sebesar satu persen maka akan menaikkan variabel pencegahan fraud sebesar 23,4

Tabel 8. Hasil Estimasi Regresi Berganda

\begin{tabular}{|c|c|c|c|c|c|c|}
\hline \multirow{2}{*}{\multicolumn{2}{|c|}{ Model }} & \multicolumn{2}{|c|}{ Unstandardized Coefficients } & \multirow{2}{*}{$\begin{array}{c}\text { Standardized } \\
\text { Coefficients }\end{array}$} & \multirow{3}{*}{$\begin{array}{l}\mathbf{t} \\
6.775\end{array}$} & \multirow{3}{*}{$\begin{array}{l}\text { Sig. } \\
\quad .000\end{array}$} \\
\hline & & B & Std. Error & & & \\
\hline 1 & (Constant) & 91.558 & 13.515 & & & \\
\hline & total_TI & .174 & .234 & .175 & .746 & .463 \\
\hline & Total_ACC & .234 & .251 & .167 & .934 & .359 \\
\hline
\end{tabular}

Sumber: Data diolah, 2018

Koefisien Determinasi $\left(\mathbf{R}^{2}\right)$

Tabel 9. Koefisien Determinasi

\begin{tabular}{lrrrr}
\hline Model & R & R Square & Adjusted R Square & \multicolumn{2}{c}{ Std. Error of the Estimate } \\
\hline 1 & $.448^{\mathrm{a}}$ & .201 & .109 & 6.52770 \\
\hline \multicolumn{2}{l}{ Sumber: Data diolah, 2018} & &
\end{tabular}

Dan hasil perhitungan regresi linear berganda di peroleh nilai Adjusted $R$ Square sebesar 0,109. Hasil ini yang menunjukkan bahwa 10,9 \% variasi perubahan pada variabel pencegahan fraud (Y) dipengaruhi oleh variabel-variabel teknologi informasi $\left(\mathrm{X}_{1}\right)$, accounting reporting $\left(\mathrm{X}_{2}\right)$ sedangkan $89,1 \%$ lainya dipengaruhi oleh variabel atau faktor lain diluar penelitian ini.

\section{Uji F}

Untuk menguji pengaruh variabel independen secara bersama-sama terhadap variabel dependen digunakan uji F. Dari hasil perhitungan dengan 
tingkat keyakinan sebesar 95 persen atau $\alpha=0,05$ diperoleh nilai $\mathrm{F}_{\text {tabel }}$ sebesar 2,119, sedangkan nilai $F_{\text {hitung }}$ sebesar 2,178. Tabel 10 menunjukkan hasil output dengan uji F.

Tabel 10. Hasil Uji F

\begin{tabular}{llrrrrr}
\hline \multicolumn{1}{l}{ Model } & \multicolumn{1}{c}{$\begin{array}{c}\text { Sum of } \\
\text { Squares }\end{array}$} & df & Mean Square & F & \multicolumn{1}{c}{ Sig. } \\
\hline 1 & Regression & 278.416 & 3 & 92.805 & 2.178 & $.115^{\mathrm{a}}$ \\
& Residual & 1107.884 & 26 & 42.611 & & \\
& Total & 1386.300 & 29 & & & \\
\hline
\end{tabular}

a. Predictors: (Constant), total_TI, Total_ACC

b. Dependent Variable: total_fraud

Sumber: Data diolah, 2018

Hal tersebut menunjukkan bahwa nilai $\mathrm{F}_{\text {hitung }}>$ nilai $\mathrm{F}_{\text {tabel }}$ atau berada pada daerah penolakan $\mathrm{H}_{0}$, sehingga dapat disimpulkan bahwa variabel teknologi informasi, accounting reporting secara bersama-sama mempunyai pengaruh yang signifikan terhadap tindakan pencegahan fraud. Sehingga dinyatakan teknologi informasi, accounting reporting secara simultan berpengaruh terhadap pencegahan fraud.

\section{Uji t}

Untuk mengetahui pengaruh secara parsial variabel teknologi informasi, accounting reporting terhadap pencegahan fraud digunakan uji t. Dari hasil analisis dengan menggunakan tingkat kesalahan $(\alpha)=0,05$ diketahui nilai $t$ tabel sebesar 0,590 .

Tabel 11. Hasil Uji t

\begin{tabular}{|c|c|c|c|c|c|c|}
\hline \multirow{2}{*}{\multicolumn{2}{|c|}{ Model }} & \multicolumn{2}{|c|}{ Unstandardized Coefficients } & \multirow{2}{*}{$\begin{array}{c}\text { Standardized } \\
\text { Coefficients }\end{array}$} & \multirow[b]{2}{*}{$\mathrm{t}$} & \multirow[b]{2}{*}{ Sig. } \\
\hline & & B & Std. Error & & & \\
\hline \multirow[t]{3}{*}{1} & (Constant) & 91.558 & 13.515 & & 6.775 & .000 \\
\hline & total_TI & .174 & .234 & .175 & .746 & .463 \\
\hline & Total_ACC & .234 & .251 & .167 & .934 & .359 \\
\hline
\end{tabular}

Sumber: Data diolah, 2018

Berdasarkan gambar dapat dijelaskan pengaruh masing-masing variabel independen terhadap variabel dependen sebagai berikut:

Pengaruh Teknologi Informasi terhadap Pencegahan Fraud

Diketahui nilai $\mathrm{t}$ hitung variabel Teknologi Informasisebesar 0,746. Dengan menggunakan $\alpha=0,05$ diperoleh nilai t tabel sebesar 0,590. Dari hasil tersebut dapat dilihat bahwa nilai $\mathrm{t}_{\text {hitung }}>$ nilai $\mathrm{t}$ tabel. Hal ini menunjukkan bahwa variabel Teknologi Informasi berpengaruh positif signifikan terhadap tindakan 
Pencegahan Fraud,sehingga hipotesis yang menyatakan bahwa Teknologi Informasi berpengaruh terhadap Pencegahan Fraud, diterima.

Diketahui nilai $\mathrm{t}$ hitung variabel accounting reporting sebesar 0,934. Dengan menggunakan $\alpha=0,05$ diperoleh nilai t tabel sebesar 0,590. Dari hasil tersebut dapat dilihat bahwa nilai $\mathrm{t}$ hitung < nilai $\mathrm{t}$ tabel- Hal ini menunjukkan bahwa variabel accounting reporting berpengaruh terhadap Pencegahan Fraud. Sehingga hipotesis yang menyatakan bahwa Accounting reporting berpengaruh terhadap Pencegahan Fraud, diterima.

\section{Pembahasan}

1. Teknologi informasi berpengaruh terhadap pencegahan fraud.

Hasil ini menunjukkan bahwa adanya implementasi teknologi informasi yang membantu kegiatan perusaahaan dalam menghasilkan informasi yang akurat berdampak sangat membantu mencegah terjadinya kecurangan (fraud) dalam organisasi perusahaan. Hasil penelitian ini sesuai dengan pernyataan yang dikemukakan oleh Wilkinson dan Cerullo (1997) yang mengatakan bahwa implementasi teknologi informasi dapat memenuhi kebutuhan informasi dunia bisnis dengan sangat cepat, tepat waktu, relevan, dan akurat sehingga mampu meminimalisir kesalahan baik yang disengaja ataupun tidak.

2. Accounting Reporting berpengaruh terhadap pencegahan fraud.

Accounting reporting merupakan komponen penting untuk menciptakan akuntabilitas organisasi. Salah satu bentuk pencegahah fraud adalah dengan menyajikan accounting reporting yang sesungguhnya dengan mempertimbangkan hal penerapan kebijakan, sistem dan prosedur yang membantu menyakinkan bahwa tindakan yang diperlukan sudah dilakukan dewan komisaris, serta manajernen dan personil lain perusahaan untuk dapat memberikan kenyakinan memadai. Hasil penelitian ini mendukung penelitian yang dilakukan oleh Santoso (2008) yang membuktikan bahwa penerapan accounting report di sector public terbukti mencegah terjadinya fraud.

\section{KESIMPULAN, KETERBATASAN DAN SARAN}

Kesimpulan dari penelitian ini adalah sebagai berikut:

1. Teknologi informasi terrbukti berpengaruh terhadap pencegahan fraud. adanya implementasi teknologi informasi yang membantu kegiatan perusaahaan dalam menghasilkan informasi yang akurat berdampak sangat membantu mencegah terjadinya kecurangan (fraud) dalam organisasi perusahaan. Hasil penelitian ini sesuai dengan pernyataan yang dikemukakan oleh Wilkinson dan Cerullo (1997) yang mengatakan bahwa implementasi teknologi informasi dapat memenuhi kebutuhan informasi 
dunia bisnis dengan sangat cepat, tepat waktu, relevan, dan akurat sehingga mampu meminimalisir kesalahan baik yang disengaja ataupun tidak.

2. Accounting reporting terbukti berpengaruh terhadap reaksi investor. Hasil penelitian ini mendukung penelitian yang dilakukan oleh Santoso (2008) yang membuktikan bahwa penerapan accounting report di sector public terbukti mencegah terjadinya fraud.

Adapun saran-saran yang dapat penulis berikan sehubungan dengan keterbatasan dalam penelitian ini adalah sebagai berikut:

1. Bagi perusahaan untuk meningkatkan kepercayaan pemegang saham terhadap perusahaan, maka perusahaan harus mampu menunjukkan kinerja perusahaan yang bagus dan menyampaikan informasi yang cukup kepada investor mengenai perkembangan perusahaan.

2. Bagi para investor dan calon investor, sebelum melakukan investasi sebaiknya mencari tahu mengenai profil perusahaan dan informasiinformasi yang diungkapkan oleh perusahaan emiten, apakah memenuhi kebutuhan informasi dalam analisis investasi.

Bagi peneliti selanjutnya diharapkan dapat menggunakan jenis perusahaan yang berbeda dan memakai ruang lingkup sampel yang luas. Selain itu juga diharapkan dapat menambah variabel-variabel lain yang dapat mempengaruhi pencegahan fraud seperti system pengendalian internal perusahaan serta reaksi investor seperti earning, tingkat bunga, dan lain-lain.

\section{REFERENSI}

Aji Supriyanto. (2005). Pengantar Teknologi Informasi . Jakarta: Salemba Infotek.

Agus Sartono, 2001. Manajemen Keuangan Teori dan Aplikasi . Yogyakarta: BPEF-YOGYAKARTA

Auditing Standard Board. 1995. Statement on Auditing Standards Number 78. American Institute of Certified Public Accountants, Inc

Caskey, J., dan M. Hanlon. 2005. Do dividends indicate honesty? The relation between dividends and the quality of earnings. Working paper, University of Michigan.

Deddi Nordiawan. 2007. Akuntansi Sektor Publik. Salemba Empat : Jakarta.

Deddi Nordiawan, Iswahyudi sondi putra, Maulidah rahmawati. 2007. Akuntansi Pemerintah. Salemba Empat: Jakarta 
Devaraj, S. and Kohli, R. 2003. "Performance Impacts Of Information Technology: Is Actual Usage The Missing Link? ”Management Science. (49:3). pp. 273-289.

Easterbrook, F. 1984. Two agency-cost explanations of dividends. The American Economic Review 74:650-659.

Ghozali, Imam. 2005. “Aplikasi Analisis Multivariate Dengan Program SPSS”. Semarang: Badan Penerbitan Universitas Diponegoro

Glassman, J. 2005. When numbers don’t add up. Kiplinger's (August): 32-34.

Goodhue,D.I dan Thompson.R.L.1995.“Task - Technology and Individual Performance”. Mis Quarterly, Juni 213-236.

Hanafi, Mamduh. (2004). “Manajemen Keuangan”, BPFE, Yogyakarta

IAI. 2009. Standar Akuntansi Keuangan. Jakarta: Salemba Empat

Jones, R dan M. Pendlebury. 2000. Public Sector Accounting. $5^{\text {th }}$ Edition. Pitman Publishing, London

Kieso, Donald E. and Jerry J. Weygandt. 2005. Accounting Principles. Canada : John Wiley \& Sons, Inc

Lintner, J. 1956. Distribution of Incomes of Corporations Among Dividends, Retained Earnings, and Taxes. The American Economic Review, Vol. 46, No. 2: 97-113.

Nunnally, J.C. 1978. Psychometric Theory. 2nd Edition, McGraw-Hill, New York.

O’Brien, James A. 2004. Management Information System : Managing Information Technology in the Business Enterprise. Sixth Edition. Mc. Graw-Hill. New York.

Rezaee, Zabihollah.2002. Prevention and detection. Canada

Santoso, Urip dan Yohanes.J.P. 2008. Pengaruh penerapan akuntansi sector public terhadap akuntabilitas kinerja instansi pemerintah dalam mencegah fraud. Jurnal admisnistrasi Bisnis Vol.4

Singarimbun,Masri dan Sofian Effendi. 1995. Metode Penelitian Survei. Jakarta : PT PustakaLP3ES Indonesia.

Suwardjono. 2005. Teori Akuntansi: Perekayasaan Pelaporan Keuangan. Edisi Ketiga, Yogjakarta: BPFE. 
Thompson, Ronald L, Haggings, Christoper A., dan Howell, Jane M. (1991),"Personal Computing: Toward a Conceptual Model of Utilization”, MisQuarterly, pp.125-143.

Tjhai fung Jing. 2003. " Analisis Faktor - faktor yang Mempengaruhi Pemanfaatan Teknologi Informasi terhadap Kinerja Akuntan Publik ". Jurnal Bisnis dan Akuntansi. 5(1):1-26.

Wibowo,., Wijaya, Winny. 2009. Pengaruh penerapan Fraud EarlyWarning System (FEWS) terhadap aktivitas bisnis perusahaan. Jurnal Informasi, Perpajakan, Akuntansi dan Keuangan Publik

Wilkinson, Joseph W., Michael J. Cerullo, Vasant Raval, Bernard Wong-onWing. 2000. Accounting Information Systems. $4^{\text {th }}$ Edition. Canada : John Willey \& Sons, Inc

Wolk, Harry. I., Michael G, Tearney., James. L. Dodd, 2001. Accounting Theory : a conceptual and institutional approach, Fifth Edition, South Western Collage Publishing, Cincinnati, Ohio.

Zuhroh, D., dan Sukmawati. 2003. "Analisis pengaruh luas pengungkapan sosial dalam laporan tahunan perusahaan terhadap reaksi investor (studi kasus pada perusahaan-perusahaan high profile di BEJ)". Simposium Nasional Akuntansi VI (SNA VI), 1314-1341. 